\title{
Pyrosequencing investigation into the bacterial communities in the Qinghai-Tibet Plateau soils associated with soil characteristic factors
}

\author{
LiangCheng $^{1,3,4}$, XINWAng $^{2}$ \& QingyunGuo ${ }^{1,3,4 *}$ \\ ${ }^{1}$ Plant Protection Institute, Qinghai Academy of Agriculture and Forestry Sciences, Qinghai University, Xining 810016, China \\ ${ }^{2}$ Soil and Fertilizer institute, Qinghai Academy of Agriculture and Forestry Sciences, Qinghai University, Xining 810016, China; \\ ${ }^{3}$ Key Laboratory of Agricultural Integrated Pest Management in Qinghai Province, Xining 810016, China \\ ${ }^{4}$ Scientifc Observing and Experimental Station of Crop Pests in Xining, Ministry of Agriculture and Rural Affairs, Xining 810016, \\ China \\ E-mail: liangcheng1979@163.com; wangx710@163.com;guoqingyunqh@163.com* \\ *corresponding author
}

\begin{abstract}
The Qinghai Tibet Plateau (QTP) is one of the most important regions of the earth's ecosystem that is vulnerable to climate and human activities due to its complex climate and terrain. However, knowledge about soil bacterial communities and their effect on the ecosystem within the QTP environments is still scarce. Metagenomic approaches on the structure and diversity of bacterial communities and their relationship with the environment from eighteen selected sites of the five major QTP ecosystems (gray-cinnamon soils, chernozems, castanozems, mountain meadow soils, gray desert soils) are presented in this paper. The dominant bacterial phyla in five type soils were Proteobacteria and Actinobacteria, whereas Actinobacteria and Chloroflexi predominated in gray desert soils. The bacteria diversity in castanozeras and mountain meadow soils was significantly higher than that of the other three soil types $(P<0.05)$. Phylogenetic diversity in gray desert soil was significantly lower than that of other four soil types $(P<0.05)$. Phylotype richness was the lowest in gray-cinnamon soils. There were significant correlations between the phylotype richness and soil moisture $(r=-0.578)$ and potassium $(r$ $=-0.529)$. Phylogenetic diversity (PD) was significantly correlated with total organic carbon $(r=-0.548)$. The redundancy analysis (RDA) showed that the diversity and composition in the bacterial communities differed greatly among the five soil types and that they were closely correlated with the soil moisture, soil organic carbon and potassium. These results indicated that the bacterial community structures of QTP soils were obviously influenced by soil characteristics and soil environmental characteristics and provided a theoretical basis for the optimal management and sustainable utilization of the QTP soil ecosystem, which is of great significance.
\end{abstract}

Keywords: bacterial community; environmental variables; high-throughput sequencing; Qinghai-Tibet Plateau; redundancy analysis

\section{YFIRLIT}

Tengsl bakteriusamfélaga við jarðvegseiginleika á Qinghai-Tibet hásléttunni rannsökuð með hitaraðgreiningu. Qinghai Tibet hásléttan (QTP) sem er fjölbreytt að jarðvegsgerð og loftslagi, sætir miklum áhrifum vegna landnýtingar og loftslagsbreytinga. Pekking á jarðvegsbakteríum og vistfræðilegri pýðingu peirra á hásléttunni er mjög takmörkuð. Með greiningu erfðamengja í jarðvegi var reynt að varpa ljósi á samsetningu 
bakterísamfélaga á 18 völdum stöðum QTP í 5 algengustu jarðvegsgerðunum (gray-cinnamon, chernozems, castanozems, mountain meadow og gray desert soils). Ríkjandi fylkingar baktería reyndust vera Proteobacteria, Actinobacteria, Actinobacteria og Chloroflexi. Fjölbreytileiki baktería í „castanozeras“ og „mountain meadow“ soils var marktækt meiri en í öðrum jarðvegsgerðum $(\mathrm{P}<0.05)$. Fjölbreytileiki baktería í ,gray desert“ jarðvegi var marktækt minni en í hinum fjórum jarðvegsgerðunum $(\mathrm{P}<0.05)$. Skyldleikagerðir voru fæstar í „,gray-cinnamon“ jarðvegi. Рað var marktæk fylgni fjölda skyldleikagerða baktería við jarðvegsraka $(\mathrm{r}=-0.578)$ og kalímagns jarðvegs $(\mathrm{r}=-0.529)$. Skyldleikafjölbreytileiki (PD) fylgdi marktækt heildar lífrænu kolefni jarðvegsins $(r=-0.548)$. Tölfræðileg greining (redundancy analysis, RDA) sýndi að fjölbreytileiki og samsetning bakteríusamfélaga var mjög mismunandi eftir jarðvegsgerðum par sem miklvægustu fylgnibreytur reyndust vera jarðvegsraki, ásamt heildamagni lífræns kolefnis og kalímagn jarðvegsins. Niðurstöðurnar benda pví til að bakteríuvist jarðvegs QTP sé háð jarðvegsgerð og umhverfispáttum, og að fræðileg pekking á pessum páttum geti verið mikilvæg til að stuðla að sjálbærri nýtingu jarðvegsins.

\section{INTRODUCTION}

Soil microorganisms play a leading role in a series of key ecosystem functions and processes, such as soil organic matter regulation and nutrient cycling, and then affect plant species diversity and soil structure (Giller et al. 2004). The soils of the Qinghai-Tibet Plateau have distinguishing microbial diversity, and these microorganisms have been well adapted to the extreme environment (Duan et al. 2020). The effects of biodiversity have been caused by climate change and human activities, which means that research on the microbial diversity plays an increasingly important role in environmental monitoring (Winding et al. 2005), energy and material fluxes (Poli et al. 2017) to develop genetic studies in species conservation (Liu et al. 2004, Li \& Zheng 2003, Arias et al. 2005) and other relevant factors. The unique environment in this region, abundant wildlife and their profound impact on the climate and environment of the surrounding areas have always attracted the attention of the scientific community. In the future, this region will remain a research hotspot and key area for the sustainable development of biodiversity and human-environment interaction in the world.

Considerable numbers and biodiversity of bacteria have been found in QTP soils. These studies focused on soil (Lin et al. 2012), glaciers (Chu et al. 2010, Wu XK et al. 2012), permafrost area (Zhang et al. 2013), alpine meadow (Bai et al. 2006, Djukic et al. 2010), lakes (Xiong et al. 2012), and the diversity of microorganisms and their correlation with the environment. Geographical distance and $\mathrm{pH}$ value have been found to be the main drivers of bacterial diversity in sediments (Xiong et al. 2012). Bacterial diversity in alpine grassland was positively correlated with plant root biomass, soil organic carbon, soil nitrogen content and aboveground biomass nitrogen and phosphorus content based on the study of 60 sample belts in the northeastern and central Qinghai-Tibet Plateau (Jing et al. 2015). Sample scale studies have shown that different vegetation types have had important effects on the bacterial diversity of alpine grassland, in which the bacterial diversity of alpine meadow was higher than that of alpine grassland (Zhang et al. 2016, Zhao et al. 2017). This is because the nutrient and water content of alpine meadow soil is higher than that of alpine grassland, and wet and fertile soil is conducive to shaping bacterial community composition (Drenovsky et al. 2004). So far, little is known about bacterial communities in the different soil ecosystems in the QTP. Conventionally, the biodiversity of QTP soil microbes can be rapidly profiled by the DNA fingerprint methods, including PCR-denaturing gradient gel electrophoresis and the clone library. However, these methods require expensive facilities and reagents and are relatively time-consuming. Currently, pyrosequencing was prevalently used in the analysis of microbial community composition in both broad and fine scales (Acosta-Martínez 
et al. 2008). This method can provide a much more detailed description of the microbial communities, especially the low-abundant species, than the above traditional methods. Therefore, this method has been shown to be a very effective technique in microbial ecology research (Roesch et al. 2007).

Faced with the current anthropogenic pressure on soil ecosystems, such as the pressure caused by the intensification of agricultural and animal husbandry and climate change, it is necessary to better understand the effects of these factors in order to predict the impacts of such changes. However, the soil microorganisms in this unique soil remain relatively unexplored except for a few culturable diversity studies (Bai et al. 2006, Zhang et al. 2007).We therefore collected soil samples from five types across the QTP, and used pyrosequencing to evaluate the bacterial communities with respect to three broad and related aims: (i) to explore the taxonomic diversity of the bacteria on QTP soils, (ii) to determine key factors in shaping the bacterial communities distribution, soil environmental characteristics, and soil characteristics, and (iii) to quantify their relative importance to bacterial community variation.

\section{MATERIALS AND METHODS}

Soil Sampling and Physicochemical Analysis This study was conducted in the northeastern part of the Qinghai-Tibet Plateau $\left(36^{\circ} 03^{\prime}-37^{\circ} 35^{\prime} \mathrm{N}\right.$, 97³7'-102 $48^{\prime} \mathrm{E}$; 2146-3815 $\mathrm{m}$ above sea level), located in Qinghai Province, and northwestern China. The local climate is highland continental, characterized as cold and long in winter, but warm and short in summer. The annual mean air temperature and precipitation are approximately $1.7{ }^{\circ} \mathrm{C}$ and $560 \mathrm{~mm}$, respectively (Zhao et al. 2006). Soil samples of different sites were collected in August, 2015, including Gahai (GH, at Gahai), Halihatu (HLHT, at Ulan), Delhi (DLH, at Haixi), Daotanghe (DTH, at Hainan), Lajishan (LJS, at Guide), Qunjia (QJ, at Huangzhong), Datong beichuan (DT at Datong), Haiyan (HY, at Haiyan), Xihai (XH, at Haibei), Ledu putai (LD, at Ledu), Heimahe (HMH, at Hainan), Xiangpihan (XPS, at
Hainan), Huangzhong (HZ, at Huangzhong), Huangyuan shenzhong (HYSZ, at Huangyuan), Datong shuobei (DTSB, at Datong), Guide hexi (GDHX, at Guide), Chaka (CHK, at Ulan), Keke (KK, at Ulan)(Figure S1). Eighteen soil samples which represent five different types of soil in the QTP (five castanozeras [CA], five mountain meadow soils [MMS], two gray cinnamon soils [GCS], three chernozems $[\mathrm{CH}]$, and three gray desert soils [GDS]) were sampled. Eighteen $10 \times 10 \mathrm{~cm}$ sampling plots with similar environmental characteristics were randomly selected within the sampled areas. Each sampling plots was separated by $10 \mathrm{~m}$. At each of the eighteen sampling plots, three subsamples (approximately $1000 \mathrm{~g}$ each) were collected from the organic layer $(15 \mathrm{~cm}$ deep) and mixed after the removal of visible roots and fresh litter, resulting in one composite sample per plot, and immediately placed into an incubator with ice packages and transported to the laboratory within $24 \mathrm{~h}$. The fresh soils were sieved through a $2-\mathrm{mm}$ mesh and divided into two subsamples. One was stored at $4{ }^{\circ} \mathrm{C}$ to determine physical and chemical properties, and the other was stored $-80{ }^{\circ} \mathrm{C}$ for extracting DNA. The protocols used for determining soil classification were copied from the methods described in previous studies (Zhang et al. 2014, Shi et al. 2010, ISS-AS and ISRIC, 1994). Soil $\mathrm{pH}$ was determined in a soil/water (1: 5 $\mathrm{w} / \mathrm{v}$ ) suspension with a $\mathrm{pH}$ meter (Delta-320, Mettler-Toledo Instruments [Shanghai] Co., Ltd). Total organic carbon (TOC) was measured with the $\mathrm{K}_{2} \mathrm{Cr}_{2} \mathrm{O}_{7}$ oxidation method (Islamet al. 1998). Total nitrogen (TN), phosphorus (P) and potassium $(\mathrm{K})$ were analyzed using a Eurovector Elemental Analyzer (Isoprime-EuroEA 3000, Milan, Italy). Soil salt content was measured with the soil solution electrical conductivity method. Soil moisture (SM) was measured gravimetrically. The soil microbial biomass carbon and microbial biomass nitrogen were estimated using the chloroform-fumigationextraction methods (Brookes et al. 1985, Vance et al. 1987). The selected soil properties are shown in Table S1. 
Soil DNA extraction and bacterial 16 S rRNA amplification

Soil DNA was extracted from a $0.5 \mathrm{~g}$ wet soil sample using an Omega Soil DNA Kit (QIAGEN Inc.; Valencia, CA, USA). The concentration of DNA was measured by using a NanoDrop 2000 spectrophotometer (Thermo Scientific; Wilmington, DE, USA). The extracted soil DNA was dissolved with $60 \mu \mathrm{L}$ TE buffer and stored at $-20^{\circ} \mathrm{C}$ until use.

An equal amount $(0.5 \mu \mathrm{g})$ of purified DNA from each sample was used as an amplification template. The V3-V4 hypervariable regions of bacterial 16S rRNA were amplified using Bac 319F/Uni 806R primers containing a barcode sequence, pad bases, and linker bases. PCR reactions were conducted with $2.0 \mu \mathrm{L}$ of template DNA $(10 \mathrm{ng}), 1.0 \mu \mathrm{L}$ of each primer (30 $\left.\mu \mathrm{mol} \mathrm{L}^{-1}\right), 2.0 \mu \mathrm{L}$ dNTPs, $0.125 \mu \mathrm{L}$ ExTaq DNA polymerase, $2.5 \mu \mathrm{L} 10 \times$ ExTaq buffer, and water to achieve a volume of $25 \mu \mathrm{L}$. PCR was performed with an initial 5 minute denaturation at $94{ }^{\circ} \mathrm{C}$. followed by 30 cycles of denaturation at $96{ }^{\circ} \mathrm{C}$ for 1 second, annealing at $55{ }^{\circ} \mathrm{C}$ for 55 seconds, and extension at $72^{\circ} \mathrm{C}$ for 1 minute (plus 2-second autoextensions per cycle), with a final extension of 10 minutes at $72{ }^{\circ} \mathrm{C}$. The same amount of PCR products from each sample was mixed into a single microcentrifuge tube to be run on an Illumina Hiseq 250PE instrument of Macrogen Inc. (Seoul, Korea).

\section{Sequence and data analysis}

The quality of the raw data was first processed using QIIME (Caporaso et al. 2010). Bacterial sequences were grouped by sample based on having the same barcode. Barcode and primer sequences were deleted, and only the first 350 bp after primer-F319 were included for further analysis. Bacterial phylotypes were identified using cd-hit and assigned to operational taxonomic units (OTUs, $97 \%$ similarity). The taxonomic identity of each phylotype was determined using the ribosomal database project classifier (Cole et al. 2009, Altschul et al.1990, Wang et al. 2007). At the OTUs level, the bacterial community comparison between samples was analyzed by Principal Coordinate Analysis (PCoA) using UNIFRAC (Lozupone\& Knight 2005). Phylogenetic diversity (PD) was estimated using Faith's index (Faith 1992, Faith et al. 2009), which provides an integrated index of phylogenetic breadth across taxonomic levels. Correlation between soil factors and soil bacterial diversity index were examined by linear regression analysis $(P<0.05)$. Statistical analysis was carried out by using SPSS 20.0 software (IBM Corp., Armon, NY Inc, USA). Data were analyzed by one-way ANOVA, using soil type as factor, followed by Fisher's least significant difference (LSD) with significance at $P<0.05$. Alpha diversity was calculated by using the taxonomic and functional metrics. Redundancy analysis (RDA) was used to analyze the relationship between environmental factors and sampling sites with CANOCO 5.0 software. All Illumine sequences data in this study were deposited to the SRA of the NCBI database under BioProject PRJNA658924.

\section{RESULTS}

Soil physicochemical characteristics

Based on the similarity of soil-forming processes and morphological feature 18 soil samples

Table 1. Comparison of SM, pH, TOC, TN, P and $\mathrm{K}$ in five different soil types.

\begin{tabular}{lcccccc}
\hline Soil type & $\mathrm{SM}^{\mathrm{a}}(\%)$ & $\mathrm{pH}$ & $\mathrm{TOC}\left(\mathrm{g} \mathrm{kg}^{-1}\right)$ & $\mathrm{TN}\left(\mathrm{g} \mathrm{kg}^{-1}\right)$ & $\mathrm{P}\left(\mathrm{g} \mathrm{kg}^{-1}\right)$ & $\mathrm{K}\left(\mathrm{g} \mathrm{kg}^{-1}\right)$ \\
\hline CA & $29.42 \pm 2.07 \mathrm{~b}$ & $8.14 \pm 0.04 \mathrm{ab}$ & $10.24 \pm 0.48 \mathrm{a}$ & $1.4 \pm 0.01 \mathrm{a}$ & $0.16 \pm 0.01 \mathrm{~b}$ & $2.43 \pm 0.03 \mathrm{a}$ \\
MMS & $38.68 \pm 0.59 \mathrm{a}$ & $8.20 \pm 0.02 \mathrm{ab}$ & $8.03 \pm 0.39 \mathrm{~b}$ & $0.9 \pm 0.01 \mathrm{ab}$ & $0.18 \pm 0.01 \mathrm{~b}$ & $2.54 \pm 0.04 \mathrm{a}$ \\
CH & $34.04 \pm 0.84 \mathrm{ab}$ & $8.31 \pm 0.01 \mathrm{a}$ & $8.61 \pm 0.75 \mathrm{ab}$ & $1.0 \pm 0.01 \mathrm{ab}$ & $0.17 \pm 0.01 \mathrm{~b}$ & $2.52 \pm 0.01 \mathrm{a}$ \\
GDS & $12.71 \pm 1.16 \mathrm{c}$ & $8.04 \pm 0.09 \mathrm{ab}$ & $4.79 \pm 0.77 \mathrm{c}$ & $0.6 \pm 0.01 \mathrm{~b}$ & $0.19 \pm 0.02 \mathrm{~b}$ & $2.19 \pm 0.01 \mathrm{~b}$ \\
GCS & $39.01 \pm 1.62 \mathrm{a}$ & $7.99 \pm 0.09 \mathrm{~b}$ & $4.65 \pm 0.65 \mathrm{c}$ & $1.2 \pm 0.01 \mathrm{a}$ & $0.39 \pm 0.04 \mathrm{a}$ & $2.38 \pm 0.03 \mathrm{a}$ \\
\hline
\end{tabular}

Data are presented as the mean \pm s.e.m. $(\mathrm{n}=4)$. Different letters indicate significantly different values $(P<0.05)$.

${ }^{a} \mathrm{SM}$ TOC, TN, P, K indicate soil moisture, total organic carbon, total nitrogen, phosphorus and potassium. 
Table 2. Pearson correlation (r) among soil characteristics.

\begin{tabular}{|c|c|c|c|c|c|c|c|c|c|}
\hline $\mathrm{r}$ & Elevation & $\mathrm{pH}$ & TOC & $\mathrm{TN}$ & $\mathrm{P}$ & $\mathrm{K}$ & Salt & SM & $\mathrm{T}^{\mathrm{b}}$ \\
\hline Elevation & 0 & & & & & & & & \\
\hline $\mathrm{pH}$ & -0.088 & 0 & & & & & & & \\
\hline TOC & -0.424 & 0.127 & 0 & & & & & & \\
\hline $\mathrm{TN}$ & -0.394 & -0.281 & $0.566^{*}$ & 0 & & & & & \\
\hline $\mathrm{P}$ & 0.291 & -0.667 & -0.306 & 0.256 & 0 & & & & \\
\hline K & 0.134 & 0.297 & 0.543 & 0.245 & -0.200 & 0 & & & \\
\hline Salt & 0.202 & -0.802 & -0.458 & -0.085 & 0.578 & -0.358 & 0 & & \\
\hline SM & 0.346 & 0.369 & 0.252 & -0.057 & 0.004 & 0.582 & -0.276 & 0 & \\
\hline $\mathrm{T}$ & -0.562 & 0.346 & 0.298 & 0.142 & -0.313 & -0.083 & -0.536 & -0.059 & 0 \\
\hline
\end{tabular}

were grouped into five different types, namely Castanozeras (CA), Mountain meadow soil (MMS), Gray cinnamon soil (GCS), Chernozem $(\mathrm{CH})$, and Gray desert soil (GDS). As can be seen from Table S1, each soil sample has its own corresponding nomenclature in the Genetic Soil Classification of China (GSCC). For example, $\mathrm{GH}$ was collected under the Achnatherum splendens in the Gahai, which is located in Haixi city. In GSCC, this soil was named GDS. According to the standard of the IUSS Working
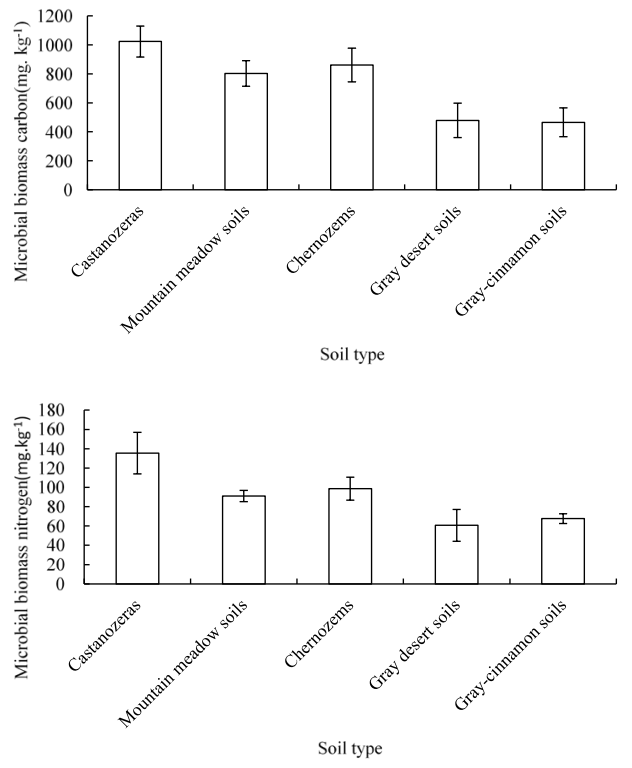

Figure 1. Comparison of soil microbial biomass carbon and nitrogen in five different soil types.
Group WRB (2006), we found that there is great variability in the maximum referencibility between soil great groups of GSCC and the World Reference Base for soil resources (WRB)
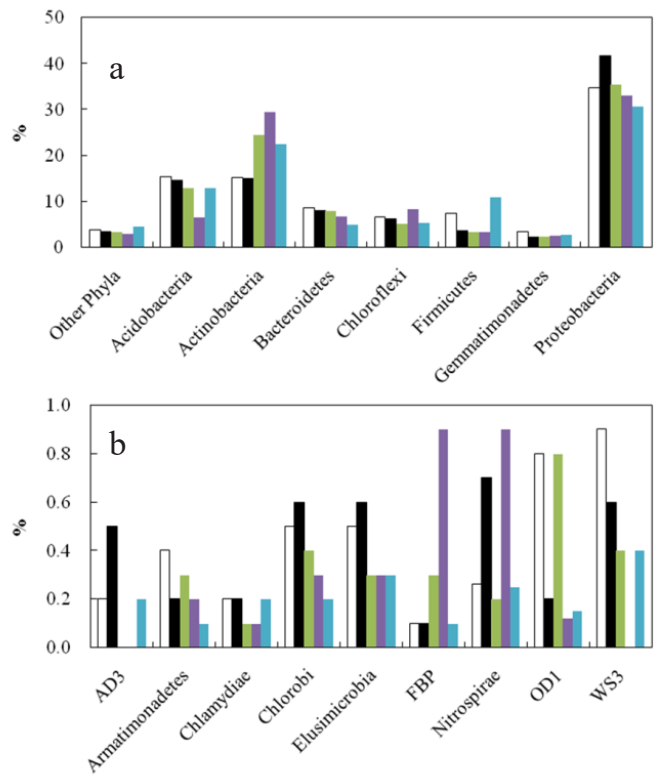

Figure 2. Frequency of bacterial phyla in different QTP soils according to the pyrosequencing analysis using Ribosomal Database Project classifiers. (a) Dominant phyla with relative frequencies $>1 \%$. (b) Rare phyla with relative frequencies $<1 \%$. (CA: Castanozeras $\square$; MMS: Mountain meadow soils $\mathbf{\square}$; $\mathrm{CH}$ : Chernozems $\square$; GDS: Gray desert soils $\square$; GCS: Gray-cinnamon soils $\square$. ) 
soil groups, which ranged from $30.7 \%$ to $78.1 \%$. For example, GCS cannot be sorted into Cambisols in WRB by reference, with maximum referencibility only being $30.7 \%$. the main reasons for this were the large differences in climatic zones, richness of soil types, and levels of economic and technological development on different continents and in different countries. The authors therefore decided that the GSCC system should be used below.

Analysis of physicochemical properties of the QTP soils showed that the soils were alkaline, ranging from $\mathrm{pH} 7.99$ to 8.31. The SM, $\mathrm{pH}, \mathrm{TN}$ and TOC differed significantly among the CA, MMS, CH, GDS and GCS. The highest average soil moisture and lowest average $\mathrm{pH}$ were found in GCS soils, followed by MMS and $\mathrm{CH}$ soils, but no significant differences were observed between the different soil types (Table 1). There was no correlation between the soil $\mathrm{pH}(\mathrm{r}=0.088, P=0.727)$, TOC $(\mathrm{r}=0.424, P=$ $0.079), \mathrm{TN}(\mathrm{r}=0.394, P=0.106)$ and the altitude of the sampling sites (Table 2). On the contrary, the TOC was significantly positively correlated with the TN $(\mathrm{r}=0.566, P<0.05)$ and $\mathrm{K}$ content $(\mathrm{r}=0.543, P<0.05)$. Soil $\mathrm{pH}$ were significantly negatively correlated with $\mathrm{K}$ content $(\mathrm{r}=-0.667$, $P<0.01)$ and salt content $(\mathrm{r}=-0.802, P<0.01)$. The SM was positively correlated with the $\mathrm{K}$ content $(\mathrm{r}=0.582, P<0.05)$.

The results showed that soil microbial biomass varied on the order of $\mathrm{CA}, \mathrm{CH}, \mathrm{MMS}$, GDS and GCS (Fig.1). The average microbial biomass carbon of CA was $1023.68 \mathrm{mg} \cdot \mathrm{kg}^{-}{ }^{1}$, which was significantly higher than that of GDS and GCS $(P<0.05)$. There was no significant difference in average microbial biomass carbon content between GDS and GCS $(P>0.05)$. Similarly, the same order of soil microbial biomass nitrogen content was found, and CA content was significantly $(P<$ 0.05 ) higher than GDS and GCS.

\section{Distribution of taxa and phylotypes}

Across all soil samples, we obtained 1,463,157 quality sequences in total, and 58,395-98,766 sequences per sample $($ mean $=81,286)$. The read lengths ranged from 362 to $550 \mathrm{bp}$, with an average of $446 \mathrm{bp}$. A total of $93.8 \%$ could be classified in these sequences. When grouped at the $97 \%$ similarity level, there were 44,265 different phylotypes in all of the soils, with an average of 3,992 phylotypes per sample.

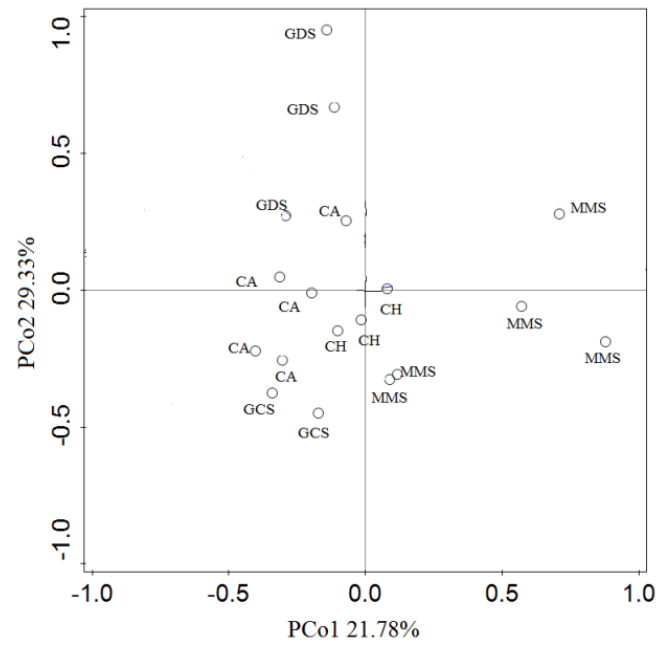

Figure 3. Bacterial community principal coordinates analysis (PCoA) using a weighted UniFrac distance matrix. The percentage variation explained by each principal coordinate is shown on the axes.
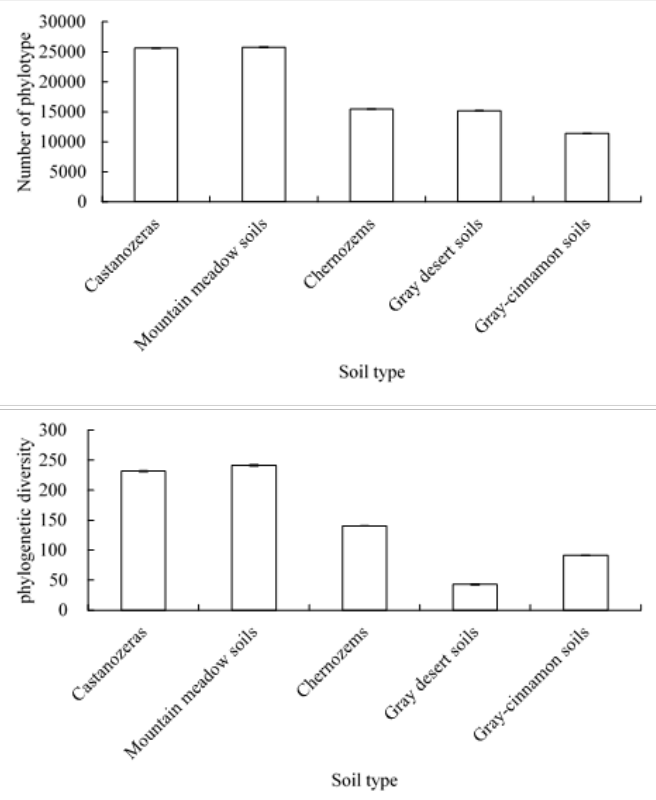

Figure 4. Soil bacterial phylotype richness and phylogenetic diversity of five morphological feature types. 
Table 3. The correlation (r) and significance $(P)$ values of linear regressions between bacterial diversity (phylogenetic diversity and phylotype richness) and soil characteristics.

\begin{tabular}{llllllllll}
\hline $\mathrm{r} / P$ & & Elevation & $\mathrm{pH}$ & $\mathrm{TOC}$ & $\mathrm{P}$ & $\mathrm{Salt}$ & $\mathrm{SM}$ & $\mathrm{TN}$ & $\mathrm{P}$ \\
\hline $\begin{array}{l}\text { phylogenetic } \\
\text { diversity }\end{array}$ & $\mathrm{r}$ & -0.120 & 0.241 & $\mathbf{- 0 . 5 4 8 *}$ & $\mathbf{- 0 . 5 5 8 *}$ & -0.122 & $\mathbf{- 0 . 4 7 5 *}$ & $\mathbf{- 0 . 5 2 9 *}$ & -0.391 \\
$\begin{array}{l}\text { (PD) } \\
\text { phylotype }\end{array}$ & $\mathrm{P}$ & 0.635 & 0.336 & 0.038 & 0.031 & 0.630 & 0.046 & 0.046 & 0.108 \\
$\begin{array}{l}\text { richness } \\
\text { (OTUs) }\end{array}$ & $P$ & 0.214 & 0.185 & 0.044 & 0.024 & 0.540 & 0.012 & 0.048 & 0.741 \\
\hline
\end{tabular}

"Values in bold type indicate factors that had significant correlations $(P<0.05)$.

Eight phyla (Proteobacteria, Gemmatimonadetes, Firmicutes, Chloroflexi, Bacteroidetes, Actinobacteria and Acidobacteria) were considered abundant with sequence frequencies of $>1 \%$ (Fig.2a), whereas 9 phyla (AD3, Armatimonadetes, Chlamydiae, Chlorobi, Elusimicrobia, FBP, Nitrospirae, OD1 and WS3) were considered low abundance with sequence frequencies of $<1 \%$ (Fig. 2b). The relative abundances of the dominant bacterial group varied among the $\mathrm{CA}, \mathrm{GCS}, \mathrm{CH}, \mathrm{MMS}$ and GDS. The prevalent taxon in five type soils was Proteobacteria, which was followed in relative abundance by Actinobacteria and Acidobacteria. In GDS, the abundance of Proteobacteria and Acidobacteria decreased, whereas that of Bacteriodetes increased significantly compared with MMS and CA. Nevertheless, the GCS were dominated by Proteobacteria and Actinobateria, followed in abundance by Acidobacteria and Firmicutes. Generally, Proteobacteria abundance decreased gradually from MMS through $\mathrm{CH}$ to GDS, that is, from 41.71 to $35.40 \%$ and $33.12 \%$, respectively. In contrast, the abundance of Actinobacteria increased from $15.04 \%$ in MMS to $24.44 \%$ in $\mathrm{CH}$ and $29.36 \%$ in GDS. Compared with GCS, the abundance of Proteobacteria in MMS and CA increased significantly $(P<0.05)$, while the abundance of Actinobacteria in MMS and CA decreased significantly $(P<0.05)$.

At the phylum level, the PCoA patterns indicated that there were distinct differences in bacterial community compositions among CA, MMS, CH, GDS and GCS (Fig. 3). All samples tended to cluster together according to their own soil characteristics. Bacteria communities
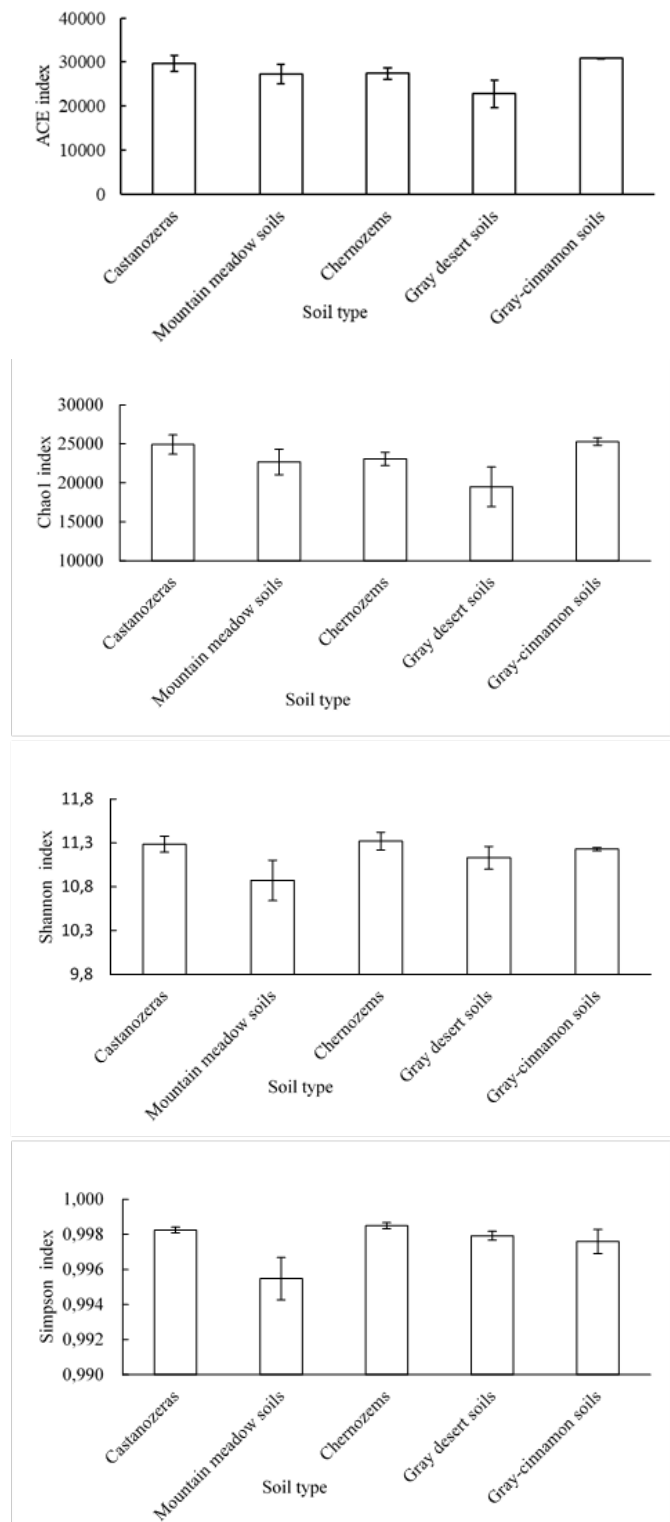

Figure 5. Diversity indices of five soil bacterial communities in QTP. 
in CA, GCS and $\mathrm{CH}$ were clearly different from those in MMS, as well as those from GDS which were relatively similar and clustered together, explaining $21.78 \%$ of the total variation along the first axis, respectively. The MMS, GCS, CA, and $\mathrm{CH}$ bacterial communities were different from those in GDS along the second axis, which accounted for $29.33 \%$ of the variation, respectively.

\section{Relationship between soil bacterial diversity and soil physicochemical properties}

Soil bacterial OTUs and PD of five soil types varied from $11,402.33$ to $25,751.33$ and from 91.42 to 241.57 , respectively (Fig. 4). The highest values of OTUs and PD were observed in CA and MMS, while the lowest values were found in GDS and GCS. The diversity of PD in GDS was significantly lower than that in the other four soil types $(P<0.05)$. In order to explore the relationship between soil bacterial alpha diversity and soil factors, the correlation between soil bacterial alpha diversity (OTUs and PD) and
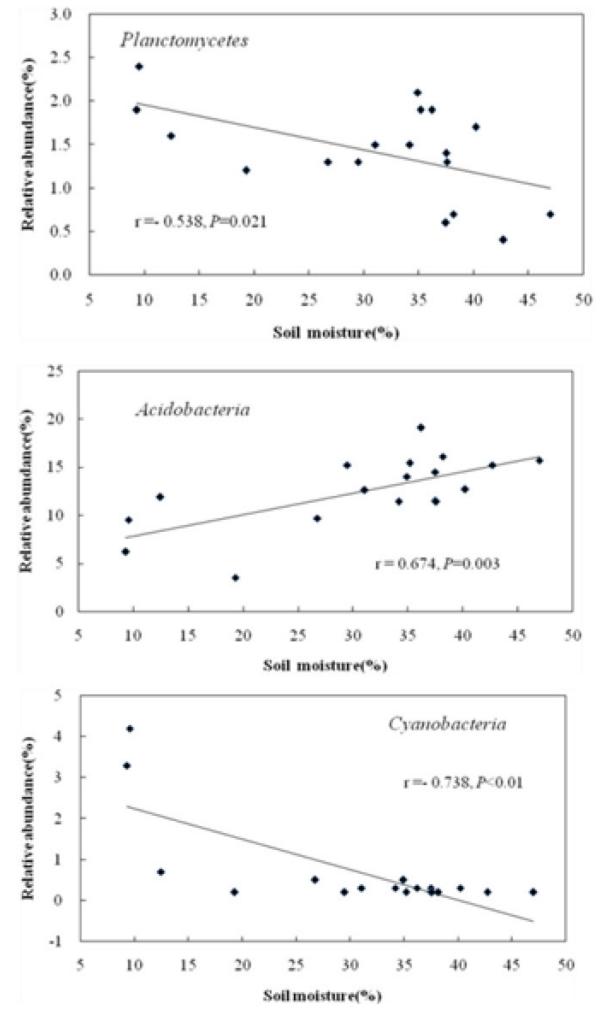

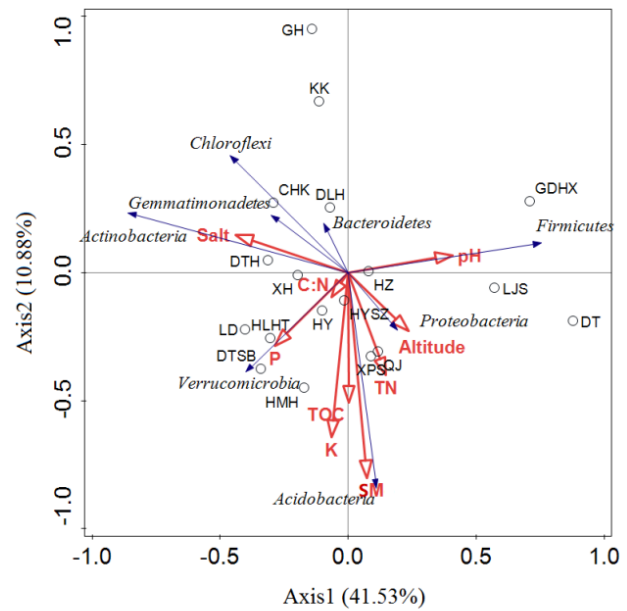

Figure 6. RDA showing associations between environmental factors and bacterial phyla.

(LD: Leduputai; HLHT: Halihatu; DTH: Datanghe;XH: Xihai; DLH: Delhi;DT: Datong Beichuan; LJS:Lajishan; GDHX: Guide hexi; XPS: Xiangpishan;QJ: Qunjia; HMH:Heimahe; DTSB: Datong shuobei; HZ: Huangzhong; HYSZ: Huangyuanshenzhong; HY: Haiyan; GH: Gahai;CK: Chaka; KK: Keke.)
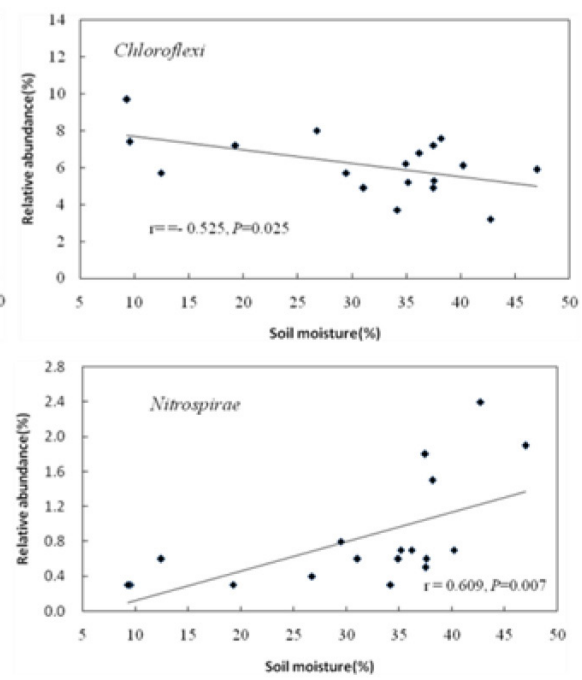

Figure 7. Linear relationships between relative abundances of dominant bacterial groups and SM. 

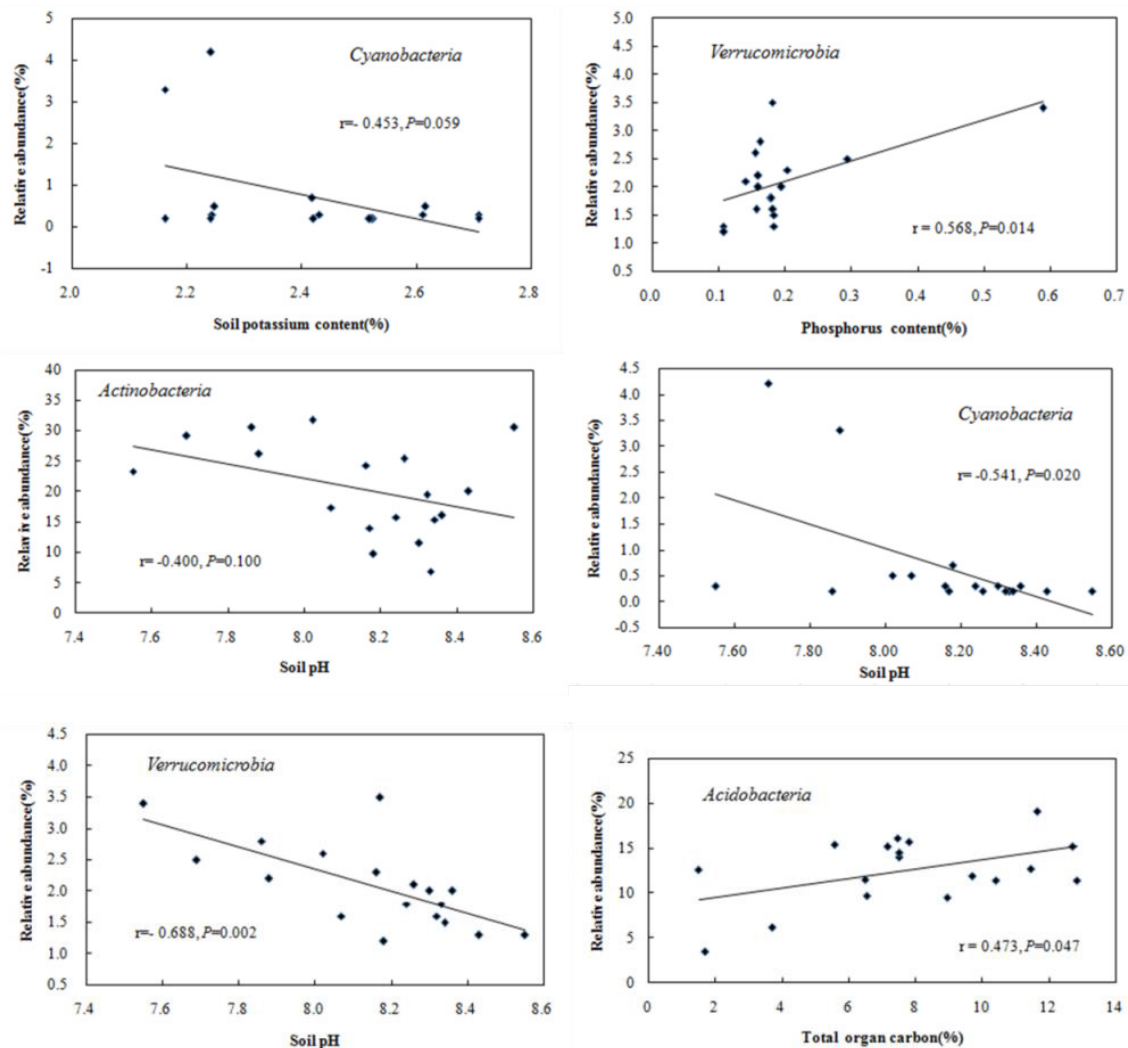

Figure 8. The relationships between relative abundances of dominant bacterial groups and soil factors, including altitude, $\mathrm{K}, \mathrm{P}, \mathrm{pH}$, and TOC, respectively.

eight soil factors (such as soil $\mathrm{pH}, \mathrm{SM}$ and TOC, etc.) was analyzed (Table 3). The results showed that SM, soil $\mathrm{K}$, TOC and TN were significantly correlated with OTUs and PD $(P<0.05)$. OTUs and PD were negatively correlated with SM $(P=0.012 ; P=0.046$, respectively $)$, and also negatively correlated with soil $\mathrm{K}(P=0.024 ; P=$ 0.031 , respectively). TOC and TN were positively correlated with OTUs $(P=0.044, P=0.048)$, and negatively correlated with $\mathrm{PD}(P=0.038, P=$ 0.046). Other soil factors and OTUs and PD did not reach significant levels $(P>0.05)$. The OTUs and PD of soil bacteria were not significantly correlated with altitude, $\mathrm{pH}$ or $\mathrm{P}$ content. The four microbial diversity indices of the five type soils were calculated respectively (Fig.5). The ACE and Chaol indices showed that the diversity and richness of microbial communities in GDS were the lowest, CA and GCS were the highest, and the Shannon and Simpson indices were very similar among the five soil types. Among the five soil types, the diversity of MMS was the lowest.

\section{Effects of soil properties on the microbial community structure}

The RDA revealed that the total percentage variance explained by the measured variables was $52.41 \%$ in the bacterial community model (Fig. 6). Across all samples, SM was the most important soil parameter for the variations in the bacterial community structures, followed by K, TOC and TN. SM had an obvious effect on the very rough classification resolution because the relative abundances of the dominant bacterial phyla (e.g. Acidobacteria and Chloroflexi), rarer phyla (e.g. Planctomycetes, Nitrospirae, and 
Cyanobacteria), were significantly correlated across the SM gradient, although sometimes in opposite directions. For instance, the relative abundance of Planctomycetes, Cyanobacteria and Chloroflexi decreased as SM increased, but Acidobacteria and Nitrospirae increased (Fig. 7). Some soil elements related to SM, such as $\mathrm{K}$ and $\mathrm{P}$, showed significant correlations with the relative abundance of Acidobacteria, Cyanobacteria and Verrucomicrobia.

The relative abundance of Verrucomicrobia $(\mathrm{r}$ $=-0.688, P=0.002)$, Planctomycetes $(\mathrm{r}=-0.486$, $P=0.041)$ and Cyanobacteria $(\mathrm{r}=-0.541, P$ $=0.020)$ were negatively correlated with soil $\mathrm{pH}$. The abundance of other bacterial groups had no relationship with the soil TOC, except Acidobacteria, which showed a not significant positive relationship with TOC $(\mathrm{r}=0.473, P=$ 0.047). The soil $\mathrm{C} / \mathrm{N}, \mathrm{TN}$, and temperature were found to have no significant relationship with the abundance of all the dominant bacterial groups. Elevation was significantly $(P<0.05$ in all cases) correlated with the relative abundances of Gemmatimonadetes, Verrucomicrobia or Nitrospira (Fig. 8). In brief, the results strongly demonstrated that local SM, directly or indirectly, affected the bacterial community structure among sites across the QTP soils.

\section{DISCUSSION}

\section{Soil bacterial community composition}

QTP is the highest and largest plateau on earth and is considered to be one of the sensitive areas of biodiversity (Zheng et al. 2000). However, until now, only a very limited number of studies have explored the soil microbial communities in QTP using 16S rRNAgene clone library approaches (Liu et al. 2009, Liu et al. 2006). Recent studies found that QTP has a formed predominant group from different environmental samples with a similar group but different abundance. For example, the differences in soil bacterial community structure among cultivated farmlands, alpine meadow and salt lake ecosystem in QTP indicated that the dominant bacteria phyla were Proteobacteria, Actinobacteria, Bacteroidetes, Acdiobacteria, and Verrucomicrobia (Guan et al. 2013). Five dominant bacteria phyla Actinobacteria, a-Proteobacteria,
Acdiobacteria, Chloroflexi and Gemmatimonadete were observed across the northwest Tibetan Plateau surface soil (Chu et al. 2016). Yuan et al. (2014) and associates indicated that Acdiobacteria, Proteobacteria and Gemmatimonadete were confirmed in Nyainqentanglha Mountain alpine grassland soil samples. In this study, we found that Proteobacteria, Actinomycete, Acidobacteria and Bacteroidetes were the dominant phyla in QTP soils and high relative abundances of Chloroflexi and Firmicutes were observed, accounting for more than $87.1 \%$. These observations were consistent with many past studies mentioned above. From the analysis of bacterial communities in different soil types, most bacterial groups were relatively stable among the GDS, GCS, CH, CA, and MMS, but several groups exhibited changes in their relative abundance. The alkalophilic Actinobacteria were consistently more abundant in GDS (Fig. 2a), which might be due to higher organic matter, low water and higher $\mathrm{pH}$. On the contrary, Proteobacteria were abundant in MMS, indicating that the bacterial communities' structure was obviously different relative to those of GDS, which agreed with the PCoA pattern, the water content abundance in this sample. This finding was consistent with results in North America (Fierer et al. 2007) and QTP soils (Wang et al. 2008).

\section{Bacterial community structure and environmental relevance}

The QTP soil bacterial communities were different despite the fact that the soils from other environments such as arctic areas or farmland share some physicochemical characteristics. Although phyla have been detected in all collected soils (including QTP), the relative frequencies of bacterial phyla differ in different niches, which are usually considered to be controlled by local environmental factors including vegetation (Marschner et al. 2001, Kowalchuk et al. 2002, Weinert et al. 2011), soil characteristics (Hansel et al. 2008, Wu et al. 2008), soil texture (Schutter et al. 2001), land use (Kennedy et al. 2005, Yergeau et al. 2007), geographic distance (Fierer \& Jackson 2006), and pH (Lauber et al. 2008), to name some relevant factors. When soil 
physicochemical parameters were considered separately, SM was the most important factor to determine soil microbial diversity in the QTP soils (Fig.4). Previous studies have shown that the moisture content of soils in QTP is positively correlated with soil organic carbon storage and vegetation coverage (Wang et al. 2008, Wu XD et al. 2012, Chu et al. 2011). In addition, the soil nutrients and moisture in the alpine meadow were higher than in the alpine steppe, and there was an exponentially decreasing trend as the vegetative cover decreased (Chu et al. 2016). This may explain why the microbial communities in MMS with higher SM were different from those in GDS and GCS. In addition, the significant covariates between SM and the bacterial community composition may be related to Acidobacteria, Nitrospirae, Chloroflexi, Planctomycetes, and Cyanobacteria, while some dominant groups were obviously related to SM. This might further suggest that the SM was the controlling factor for the bacterial species structure in QTP. These results are consistent with surveys of Antarctic soils, the Canadian Low Arctic Tundra (Chong et al. 2010) and the QTP North Slope permafrost (Guan et al. 2013), where soil moisture has a great influence on the composition of soil bacterial communities.

Although SM is the main environmental factor affecting the composition of soil bacterial communities, other factors were also shown to affect the distribution of microbial communities in different environments. For example, the community of Estuarine bacterioplankton varies along the salinity gradient (Crump et al. 2004), and the bacterial structures in high salinity and sediment soils are significantly correlated with the content of TOC (Hollister et al. 2010). Phylotype richness was inversely correlated with soil TOC, which is in agreement with the results observed in the black soil zone in northeast China (Liu et al. 2014), suggesting that soil TOC is another important factor predicting bacterial communities. Therefore, considering that the significant positive correlation between TOC, $\mathrm{TN}$ and $\mathrm{K}$ contents in QTP soil, we deduce that $\mathrm{K}$ is also an important factor determining the
QTP soil bacterial community structures, which can be explained by a series of higher K levels with specific environmental conditions and geographical locations in QTP soil. Meanwhile, RDA analysis also showed that significant correlations between the $\mathrm{K}$ content and bacterial community composition were observed in QTP soils (Fig.6), indicating that the K content in soil was the main environmental factor affecting the bacterial community distribution.

The soil $\mathrm{pH}$ also has a strong impact on the structure and diversity of soil bacterial communities (Chu et al. 2010, Chong et al. 2010, Lauber et al. 2009). However, the soil pH was not the most important soil factor in the current study and the distribution pattern of bacterial community structure differed from previous studies. For instance, previous work found that the relative abundance of bacterial community has been shown to increase with higher $\mathrm{pH}$ (Chu et al. 2010, Rousk et al. 2010), but bacterial community structure and $\mathrm{pH}$ were not significantly associated in the current study. The narrow $\mathrm{pH}$ range of the samples from our eighteen locations may account for this difference. The $\mathrm{pH}$ ranged from 7.99 to 8.31 at eighteen locations, whereas the $\mathrm{pH}$ ranges in other investigations were 4.0-7.64 (Chu et al. 2010), 3.30-7.24 (Nacke et al. 2011), 3.30-7.37 (Zinger et al. 2011) and 3.50-8.50 (Fierer et al. 2006).

The elevational diversity gradient is one of the most basic models in animal and plant biogeography. Here we observed that there was no apparent elevation gradient of soil bacterial diversity on QTP, neither monotonous nor unimodal within microorganisms, which is in agreement with the findings of Zhang et al. (2013) and Fierer et al. (2011). These results suggest that bacterial distribution may not follow the patterns of plants and animals in conjunction with elevation.

\section{CONCLUSION}

This study showed that soil physicochemical factors, in particular SM, soil TOC, and $\mathrm{K}$, were the main factors explaining the variation in bacterial communities in QTP soils, and a relatively high diversity of the bacterial 
community was observed in CA and MMS. Further studies with more environmental variables on a larger scale will provide further insights into the factors that drive microbial communities in this unique environment.

\section{ACKNOWLEDGMENTS}

We thank George Lazarovits for technical help as well as for general assistance. Funding for this study was provided by the Science and Technology Department of Qinghai Province (2018-ZJ-917).

\section{REFERENCES}

Altschul SF, Gish W, Miller W, Myers EW \& Lipman

DJ 1990. Basic local alignment search tool. Journal of Molecular Biology 215, 403-410.

https://doi.org/10.1016/S0022-2836 (05)80360-2

Arias ME, Gonzalez-Perez JA, Gonzalez-Vila FJ \& Ball AS 2005. Soil health - A new challenge for microbiologists and chemists. International Microbiology 1, 13-21.

https://doi.org/10.2436/IM.V8I1.9493

Acosta-Martínez V, Dowd SE, Sun Y \& Allen VG 2008. Tag-encoded pyrosequencing analysis of bacterial diversity in a single soil type as affected by management and land use. Soil Biology \& Biochemistry 40, 2762-2770.

https://doi.org/10.1016/j.soilbio.2008.07.022

Bai Y, Yang DQ, Wang JH, Xu SJ, Wang XX \& An LZ 2006. Phylogenetic diversity of culturable bacteria from alpine permafrost in the Tianshan Mountains, northwestern China. Research in Microbiology 8, 741-751.

https://doi.org/10.1016/j.resmic.2006.03.006

Brookes PC, Landman A, Pruden G \& Jenkinson DS 1985. Chloroform fumigation and the release of soil nitrogen: a rapid direct extraction method to measure microbial biomass nitrogen in soil. Soil Biology \& Biochemistry 6, 837-842.

https://doi.org/10.1016/0038-0717(85)90144-0

Caporaso JG, Kuczynski J, Stombaugh J, Bittinger K, Bushman FD, Costello EK, Fierer N, Peña AG, Goodrich JK, Gordon JI, Huttley GA, Kelley ST, Knights D, Koenig JE, Ley RE, Lozupone CA, McDonald D, Muegge BD, Pirrung M, Reeder J, Sevinsky JR, Turnbaugh PJ, Walters WA, Widmann J, Yatsunenko T,
Zaneveld J \& Knight R 2010. QIIME allows analysis of high-throughput community sequencing data. Natural Methods 5, 335-336.

https://doi.org/10.1038/nmeth.f.303

Chong CW, Pearce DA, Convey P, Tan GYA, Wong RCS \& Tan IKP 2010. High levels of spatial heterogeneity in the biodiversity of soil prokaryotes on Signy Island, Antarctica. Soil Biology \& Biochemstry 4,601-610.

https://doi.org/10.1016/j.soilbio.2009.12.009

Chu HY, Fierer N, Lauber CL, Caporaso JG, Knight R \& Grogan P 2010. Soil bacterial diversity in the Arctic is not fundamentally different from that found in other biomes. Environmental Microbiology 11, 2998-3006.

https://doi.org/10.1111/j.1462-2920.2010.02277.x

Chu HY, Neufeld JD, Walker VK \& Grogan P 2011. The influence of vegetation type on the dominant soil bacteria, archaea, and fungi in a low arctic tundra landscape. Soil Science Society of America Journal 5, 1756-1765.

https://doi.org/10.2136/sssaj2011.0057

Chu HY, Sun HB, Tripathi BM, Adams JM, Huang R, Zhang YJ \& Shi Y 2016. Bacterial community dissimilarity between the surface and subsurface soils equals horizontal differences over several kilometers in the western Tibetan Plateau. Environmental Microbiology 5, 1523-1533.

https://doi.org/10.1111/1462-2920.13236

Cole JR, Wang Q, Cardenas E, Fish J, Chai B, Farris RJ, Kulam-Syed-Mohideen AS, McGarrell DM, Marsh T, Garrity GM \& Tiedje JM 2009. The Ribosomal Database Project: Improved alignments and new tools for rRNA analysis. Nucleic Acids Research 37, 141-145.

https://doi.org/10.1093/nar/gkn879

Crump BC, Hopkinson CS, Sogin ML \& Hobbie JE 2004. Microbial biogeography along an estuarine salinity gradient: Combined influences of bacterial growth and residence time. Applied and Environmental Microbiology 3, 1494-1505. https://doi.org/10.1128/AEM.70.3.1494-1505.2004

Djukic I, Zehetner F, Mentler A \& Gerzabek MH 2010. Microbial community composition and activity in different Alpine vegetation zones. Soil Biology \& Biochemistry 2, 155-161.

https://doi.org/10.1016/j.soilbio.2009.10.006 
Drenovsky RE, Vo DTT, Graham KJ \& Scow KM 2004. Soil water content and organic carbon availability are major determinants of soil microbial community composition. Microbial Ecology 3, 424-430. https://doi.org/10.1007/s00248-003-1063-2

Duan P, Zhang YC, Wang JG, Wang T \& Zhao ZZ 2020. Functional diversity of soil microbial communities during degradation of alpine wetlands in Qinghai-Tibet Plateau. Acta Agrestia Sinica 3,759-767. https://doi.org/10.11733/j.issn.1007-0435.2020.03.021

Faith DP1992. Conservation evaluation and phylogenetic diversity. Biological Conservation 1, 1-10. https://doi.org/10.1016/0006-3207 (92)91201-3

Faith DP, Lozupone CA, Nipperess D \& Knight R 2009. The cladistic basis for the phylogenetic diversity (PD) measure links evolutionary features to environmental gradients and supports broad applications of microbial ecology's "phylogenetic beta diversity" framework. International Journal of Molecular Sciences 11, 4723-4741.

https://doi.org/10.3390/ijms10114723

Fierer N, Bradford MA \& Jackson RB 2007. Toward an ecological classification of soil bacteria. Ecology 6, 1354-1364.

https://doi.org/10.1890/05-1839

Fierer N \& Jackson RB 2006. The diversity and biogeography of soil bacterial communities. Proceedings of the National Academy of Sciences of the United States of America 103, 626-631.

https://doi.org/10.1073/pnas.0507535103

Fierer N, McCain CM, Meir P, Zimmermann M, Rapp JM, Silman MR \& Knight R 2011. Microbes do not follow the elevational diversity patterns of plants and animals. Ecology 4, 797-804.

https://doi.org/10.1890/10-1170.1

Guan XY, Wang JF, Zhao H, Wang JJ, Luo X, Liu F \& Zhao FQ 2013. Soil bacterial communities shaped by geochemical factors and land use in a less-explored area, Tibetan Plateau. BMC Genomics 1, 820-833. https://doi.org/10.1186/1471-2164-14-820

Giller PS, Hillebrand H, Berninger UG, Gessner MO, Hawkins S, Inchausti P, Inglis C, Leslie H, Malmqvist B, Monaghan MT, Morin PJ \& O'Mullan G 2004. Biodiversity effects on ecosystem functioning: Emerging issues and their experimental test in aquatic environments. Oikos 104, 423-436. https://doi.org/10.1111/j.0030-1299.2004.13253.x
Hansel CM, Fendorf S, Jardine PM \& Francis CA 2008. Changes in bacterial and archaeal community structure and functional diversity along a geochemically variable soil profile. Applied \& Environmental Microbiology 5, 1620-1633.

https://doi.org/10.1128/AEM.01787-07

Hollister EB, Engledow AS, Hammett AM, Provin TL, Wilkinson HH \& Gentry TJ 2010. Shifts in microbial community structure along an ecological gradient of hypersaline soils and sediments. The ISME Journal 6, 829-838.

https://doi.org/10.1038/ismej.2010.3

Islam KR \& Weil RR 1998. A rapid microwave digestion method for colorimetric measurement of soil organic carbon. Communications in Soil Science \& Plant Analysis 15-16, 2269-2284. https://doi.org/10.1080/00103629809370110

ISS-AS\&ISRIC. 1994. Soil reference profiles of the People's Republic of China, field and analytical data, pp. 1-128. Country Report 2.

IUSS Working Group WRB, 2006. World Reference Base for Soil Resources. FAO, Rome. World Soil Resources Reports No.103.

Jing X, Sanders NJ, Shi Y, Chu HY, Classen AT, Zhao K, Chen LT, Shi Y, Jiang YX \& He JS 2015. The links between ecosystem multifunctionality and above- and below-ground biodiversity are mediated by climate. Nature Communications 6,8159 .

https://doi.org/10.1038/ncomms9159

Kennedy N, Connolly J \& Clipson N 2005. Impact of lime, nitrogen and plant species on fungal community structure in grassland microcosms. Environmental Microbiology 6, 780-788. https://doi.org/10.1111/j.1462-2920.2004.00638.x

Kowalchuk GA, Buma DS, Boer WD, Klinkhamer PGL \& Veen JAV 2002. Effects of above-ground plant species composition and diversity on the diversity of soil-borne microorganisms. Antonie Van Leeuwenhoek 81, 509-520. https://doi.org/10.1023/A:1020565523615

Lauber CL, Hamady M, Knight R \& Fierer N 2009. Pyrosequencing-based assessment of soil $\mathrm{pH}$ as a predictor of soil bacterial community structure at the continental scale. Applied \& Environmental Microbiology 15, 5111-5120.

https://doi.org/10.1128/AEM.00335-09

Lauber CL, Strickland MS, Bradford MA \& Fierer $\mathbf{N}$ 2008. The influence of soil properties on 
the structure of bacterial and fungal communities across land-use types. Soil Biology \& Biochemistry 9, 2407-2415.

https://doi.org/10.1016/j.soilbio.2008.05.021

Li Y \& Zheng CY 2003. The conservation of microbial species diversity and the collection of microbial resources. Amino Acids and Biotic Resource 3, 4-6. https://doi.org/10.3969/j.issn.1006-8376.2003.03.002

Lin SL, Lin Q, Li XR, Xu H, Yang YX, Qiao DR \& Cao Y 2012. Biodiversity of the oleaginous microorganisms in Tibetan Plateau. Brazilian Journal of Microbiology 2, 627-634.

https://doi.org/10.1590/S1517-83822012000200026

Liu GX, Ma XJ, Chen T, An LZ \& Wang XL 2004. Progress and significance of studies on microorganisms in permafrost sediments. Journal of Glaciology \& Geocryology 2, 188- 191. https://doi.org/10.1016/S0960-0779 (03)00420-X

Liu JJ, Sui YY, Yu ZH, Shi Y, Chu HY, Jin J, Liu XB \& Wang GH 2014. High throughput sequencing analysis of biogeographical distribution of bacterial communities in the black soils of northeast China. Soil Biology \& Biochemistry 70,113-122. https://doi.org/10.1016/j.soilbio.2013.12.014

Liu YQ, Yao TD, Jiao NZ, Kang SC, Zeng YH \& Huang SJ 2006. Microbial community structure in moraine lakes and glacial meltwaters, Mount Everest. FEMS Microbiology Letters 1, 98-105. https://doi.org/10.1111/j.1574-6968.2006.00477.x

Liu YQ, Yao TD, Jiao NZ, Kang SC, Xu BQ, Zeng YH, Huang SJ \& Liu XB 2009. Bacterial diversity in the snow over Tibetan Plateau Glaciers. Extremophiles 3, 411-423. https://doi.org/10.1007/s00792-009-0227-5

Lozupone C \& Knight R 2005. UniFrac: Anew phylogenetic method for comparing microbial communities. Applied \& Environmental Microbiology $12,8228-8235$.

https://doi.org/10.1128/AEM.71.12.8228-8235.2005

Marschner P, Yang CH, Lieberei R \& Crowley DE 2001. Soil and plant specific effects on bacterial community composition in the rhizosphere. Soil Biology and Biochemistry 11, 1437-1445. https://doi.org/10.1016/S0038-0717(01)00052-9

Nacke H, Thürmer A, Wollherr A, Will C, Hodac L, Herold N.Schöning I, Schrumpf M \& Daniel R 2011. Pyrosequencing-based assessment of bacterial community structure along different management types in German forest and grassland soils. Plos one
2, e17000.

https://doi.org/10.1371/journal.pone. 0017000

Poli A, Finore I, Romano I, Gioiello A, Lama L \& Nicolaus B 2017. Microbial diversity in extreme marine habitats and their biomolecules. Microorganisms 2, 25.

https://doi.org/10.3390/microorganisms5020025

Roesch LFW, Fulthorpe RR, Casella ARG, Hadwin AKM., Kent AD, Daroub SH, Camarga FAO, Farmerie GW \& Triplett EW 2007. Pyrosequencing enumerates and contrasts soil microbial diversity. The ISME Journal 1, 283-290.

https://doi.org/10.1038/ismej.2007.53

Rousk J, Bååth E, Brookes PC, Lauber CL, Lozupone C, Caporaso JG, Knight R \& Fierer N 2010. Soil bacterial and fungal communities across a pH gradient in an arable soil. The ISME Journal 4, 1340-1351.

https://doi.org/10.1038/ismej.2010.58

Schutter ME, Sandeno JM \& Dick RP 2001. Seasonal, soil type, and alternative management influences on microbial communities of vegetable cropping systems. Biology \& Fertility of Soils 6, 397-410. https://doi.org/10.1007/s00374-001-0423-7

Shi XZ, Yu DS, Xu SX, Warner ED, Wang HJ, Sun WX, Zhao YC \& Gong ZT 2010. Cross-reference for relating genetic soil classification of China with WRB at different scales. Geoderma, 155, 344-350. https://doi.org/10.1016/j.geoderma.2009.12.017

Vance ED, Brookes PC \& Jenkinson DS 1987. An extraction method for measuring soil microbial biomass C. Soil Biology \& Biochemistry 6, 703-707. https://doi.org/10.1016/0038-0717(87)90052-6

Wang GX, Li YS, Wang YB \& Wu QB 2008. Effects of permafrost thawing on vegetation and soil carbon pool losses on the Qinghai-Tibet Plateau, China. Geoderma 1-2,143-152.

https://doi.org/10.1016/j.geoderma.2007.10.023

Wang Q, Garrity GM, Tiedje JM \& Cole JR 2007. Naive Bayesian classifier for rapid assignment of rRNA sequences into the new bacterial taxonomy. Applied \& Environmental Microbiology 16, 52615267. https://doi.org/10.1128/AEM.00062-07

Weinert N, Piceno Y, Ding GC, Meincke R, Heuer H, Berg G. Schloter M, Andersen G \& Smalla K 2011. Phylochip hybridization uncovered an enormous bacterial diversity in the rhizosphere of different potato cultivars: Many common and few cultivar-dependent 
taxa. FEMS Microbiology Ecology 3, 497-506.

https://doi.org/10.1111/j.1574-6941.2010.01025.x

Winding A, Hund-Rinke K \& Rutgers M 2005. The use of microorganisms in ecological soil classification and assessment concepts. Ecotoxicology \& Environmental Safety 2, 230-248.

https://doi.org/10.1016/j.ecoenv.2005.03.026

Wu TH, Chellemi DO, Graham JH, Martin KJ \& Rosskopf EN 2008. Comparison of soil bacterial communities under diverse agricultural land management and crop production practices. Microbial Ecology 2, 293-310. https://doi.org/10.1007/s00248-007-9276-4

Wu XK, Zhang W, Liu GX, Yang X, Hu P, Chen T, Zhang GS \& Li ZQ 2012. Bacterial diversity in the foreland of the Tianshan No.1 glacier, China. Environmental Research Letter 1, 14038-14046. https://doi.org/10.1088/1748-9326/7/1/014038

Wu XD, Zhao L, Chen MJ, Fang HB, Yue GY, Chen J, Pang QQ, Wang ZW \& Ding YJ 2012. Soil organic carbon and its relationship to vegetation communities and soil properties in permafrost areas of the Central Western Qinghai-Tibet Plateau, China. Permafrost and Periglacial Processes 2,162-169. https://doi.org/10.1002/ppp.1740

Xiong JB, Liu YQ, Lin XG, Zhang HY, Zeng J, Hou JZ, Yang YP, Yao TD, Knight R \& Chu HY 2012. Geographic distance and $\mathrm{pH}$ drive bacterial distribution in alkaline lake sediments across Tibetan Plateau. Environmental Microbiology 9, 2457-2466. https://doi.org/10.1111/j.1462-2920.2012.02799.x

Yergeau E, Bokhorst S, Huiskes AHL, Boschker HTS, Aerts R \& Kowalchuk GA 2007. Size and structure of bacterial, fungal and nematode communities along an Antarctic environmental gradient. FEMS Microbiology Ecology 2, 436-451. https://doi.org/10.1111/j.1574-6941.2006.00200.x

Yuan YL, Si GC, Wang J, Luo TX \& Zhang GX 2014. Bacterial community in alpine grasslands along altitudinal gradient on the Tibetan Plateau. FEMS Microbiology Ecology 1, 121-132. https://doi.org/10.1111/1574-6941.12197

Zhang XF, Zhao L, Xu SJ, Liu YZ, Liu HY \& Cheng GD 2013. Soil moisture effect on bacterial and fungal community in Beilu River (Tibetan Plateau) permafrost soils with different vegetation types. Journal of Applied Microbiology 4, 1054-1065.

https://doi.org/10.1111/jam.12106
Zhang Y, Dong SK, Gao QZ, Liu SL, Zhou HK, Ganjurjav H \& Wang XX 2016. Climate change and human activities altered the diversity and composition of soil microbial community in alpine grasslands of the Qinghai-Tibetan Plateau. Science of the Total Environment 562, 353-363.

https://doi.org/10.1016/j.scitotenv.2016.03.221

Zhang QS 2000. Uplift and environmental changes of the Tibetan Plateau. In: Zheng D, Zhang QS \& Wu SH (eds.) Mountain Geoecology and Sustainable Development of the Tibetan Plateau. Kluwer Academic Publishers, Springer, Dordrecht, pp.19-45.

Zhang GS, Ma XJ, Niu FJ, Dong MX, Feng HY, An LZ \& Cheng GD 2007. Diversity and distribution of alkaliphilic psychrotolerant bacteria in the QinghaiTibet Plateau permafrost region. Extremophiles 11, 415-424.

https://doi.org/10.1007/s00792-006-0055-9

Zhang WL, Xu AG, Zhang RL \& Ji HJ 2014. Review of soil classification and revision of China soil classification system. Scientia Agricultura Sinica, 16, 3214-3230.

https://doi.org/doi: 10.3864/j.issn.0578-1752.2014.16.009

Zhao K, Jing X, Sanders NJ, Chen LT, Shi Y, Flynn DFB, Wang Y, Chu HY, Liang WJ \& He JS 2017. On the controls of abundance for soil-dwelling organisms on the Tibetan Plateau. Ecosphere 7, e01901.

https://doi.org/10.1002/ecs2.1901

Zhao L, Li Y, Xu SX, Zhou HK, Gu S, Yu GR \& Zhao XQ 2006. Diurnal, seasonal and annual variation in net ecosystem $\mathrm{CO}_{2}$ exchange of an alpine shrubland on Qinghai-Tibetan plateau. Global Change Biology 10, 1940-1953. https://doi.org/10.1111/j.1365-2486.2006.01197.x

Zheng D, Zhang QS \& Wu SH 2000. Mountain Geoecology and Sustainable Development of the Tibetan Plateau. The Springer Netherlands: Kluwer Academic Publishers, pp. 203-204.

Zinger L, Lejon DPH, Baptist F, Bouasria A, Aubert S, Geremia RA, Aubert S, Geremia RA \& Choler P 2011. Contrasting diversity patterns of crenarchaeal, bacterial and fungal soil communities in an alpine landscape. Plos one 5, e19950.

https://doi.org/10.1371/journal.pone.0019950

Manuscript received 24.4.2020 Accepted 17.9.2020 